\title{
Conceptual Framework of Effective Interaction Between Employers and Universities on the Basis of Competence Approach
}

\author{
A. V. Babikova \\ Southern Federal University \\ annafeat@gmail.com \\ Rostov-on-Don, Russian Federation
}

\author{
A. V. Khanina \\ Taganrog Institute of Management and Economics \\ Taganrog, Russian Federation \\ anna_smash@mail.ru
}

\begin{abstract}
The given article is devoted to topical issues of searching the effective forms of partnership between employers and educational institutions. Actualization of innovative development on the background of the technological modernization of the economy, involves the growth of scientific interest in the study of new phenomena that determine the functioning of the labor market in both the individual regions of the country and as a whole in the context of description and systematization of factors that directly affect the efficiency of the industrial enterprises. Each technological change leads to a change in the characteristics of professions and employment. Digital economy requires the employee to obtain a specific set of competencies, which, at first glance, are not even peculiar to his profession. In this connection, the development of conceptual framework of interaction between employers and universities for the purpose of finding forms of strategic partnership on the basis of professional competencies formation, will help to identify a set of skills and knowledge necessary for the development of future employees to obtain the desired position.
\end{abstract}

Keywords-competency-based approach; partnership; labor market; partnerships; industrial enterprises; education

\section{INTRODUCTION}

The key features of the emerging innovation economy are new technologies and products that are created in digital form. Modern technologies have overlapping zones of influence, interact with each other in a complicated manner, form the basis of an emerging economy and refer to intellectual resources owned by various organizations, individuals and society as a whole. Implementation of the digital economy concept is based on the following operations with the intellectual resources: reproduction, use, exchange, purchase and sale. Thus, there arises a need for training highly skilled personnel of new formation, capable of working in the conditions of digital economy, taking into account the trend of intellectualization of professions, as well as current requirements of employers, including the development of management skills, digital competences, skills in communication and training throughout the whole life. Such requirements are directly related to the problem of matching between the education market and the needs of business and organizations. Taking into account the fact that modern enterprises form their own competency model, which may include both common and individual characteristics, caused by industry's particularities, it is necessary to develop such forms of partnership that result in training highly-demanded professionals capable of working in modern conditions.

The purpose of the study is to offer improved forms and interaction methods between industrial enterprises and educational institutions in the context of the formation of competitive specialists, taking into account the trend of intellectualization of professions, and also taking into account the current requirements of employers.

\section{METHODS OF RESEARCH}

In the process of research methods of theoretical generalization, calculation of the production function, methods of statistical and historical groupings, monographic, abstractlogical, as well as methods of socio-economic research, graphic interpretation of the received information were used.

\section{ANALYSIS OF FACTORS OF INDUSTRIAL DEVELOPMENT IN THE REGION WHERE UNIVERSITIES AND ENTERPRISES} OPERATE

An interaction between universities and enterprises can be developed within the frameworks of scientific and technological activities and implementation of the obtained results in industry which significantly reduces the innovation cycle and promotes innovative development of enterprises, industries and territories on the basis of activation of innovation potential in both universities and enterprises [1]. Besides, in conditions of digital transformation the human potential becomes the key production factor, which makes it necessary to develop forms of cooperation between employers and higher education institutions in the preparation of highly qualified personnel demanded by modern economy [3]. The aim of the present study is to determine the particular factor having the greatest effect on the innovation development of industry in the region with universities and enterprises in order to find the most effective direction of their interaction. The solution of the above task is obtained by calculating the production function. Basing on the given results it will be possible to propose effective forms of cooperation between educational and industrial sectors. 
The present study has been carried out on the materials of Southern Federal District. Innovative and industrial clusters, enterprises and higher education institutions, including universities, federal, regional divisions of leading metropolitan universities, are presented in the district. All these elements interact as part of the innovation process, generate and implement innovations, at the same time developing the district economy.

All factors of production perform in cooperation. In order to provide maximum production outputs with minimum inputs, required is a certain combination of production factors, which is achieved by constructing a production function [6].

If to present all the factors of production in the form of labor, materials and capital inputs, the production function can be mathematically represented as follows:

$$
\mathrm{Y}=\mathrm{A} * \mathrm{Lb} * \mathrm{Ka} \text {, }
$$

where: $\mathrm{Y}$ is the total production (a real value of all goods produced in the given year);

$\mathrm{L}$ is the labor input (number of employees engaged in research and development);

$\mathrm{K}$ is the volume of invested capital (a real value of machinery, equipment and buildings, as well as investments in fixed capital);

\section{A is the total productivity of factors;}

$\mathrm{a}$ and $\mathrm{b}$ are the elasticity of labor and capital, respectively (these values are determined by available technologies).

If the sum of constants $a$ and $b$ is equal to one, then it is assumed that such a function has a permanent effect of economies of scale. The Cobb-Douglas model is possible to apply for any particular company or industry. In this case, "a" is the portion of total inputs spent on the capital, and " $b$ " is the portion spent on the labor costs. The Cobb-Douglas models may also contain more than two variables. Within the framework of the present study, added has been the third variable "I", that is the given industry enterprises' innovation activity, and calculated are the coefficients reflecting the efficiency of each production factor contribution, represented in Table 1 below.

In order to reduce the received values to a single scale, the $[0,1]$ interval, we perform the normalization of data after the calculation of each block according to the formula:

$$
\left(\left(x-x \_ \text {min }\right)\left(d \_2-d \_1\right)\right) /\left(x \_m a x-x \_m i n\right)
$$

where $x$ is the value to be normalized, [ $x \_m a x, x \_m i n$ ] is the maximum and minimum value of the interval, [d1, d2] is the interval which the $\mathrm{x}$ value will be reduced to.

The key activities of enterprises operating in the Southern Federal District are the following: software development, ITconsulting and other related services, production of computers, electronic and optical devices, wholesale and retail trade, manufacturing of electrical equipment. The most important industries, which determine the District rank in the Russian economy, are the sectors of information and communication technologies.

Thus, having identified the present study peculiarities and the key activities of the Southern Federal District, the production function has been calculated, as well as the obtained coefficients have been normalized. After that, we obtain the following results (Table 1).

TABLE I. COEFFICIENT OF THE PRODUCTION FACTORS USE EFFICIENCY

\begin{tabular}{|l|l|l|l|l|}
\hline Sector & a1 (capital) & $\begin{array}{c}\text { a2 } \\
\text { (labor) }\end{array}$ & $\begin{array}{c}\text { a3 } \\
\text { (innovatio } \\
\text { ns) }\end{array}$ & $\begin{array}{c}\text { a0 } \\
\text { (total } \\
\text { productiv } \\
\text { ity of } \\
\text { factors) }\end{array}$ \\
\hline $\begin{array}{l}\text { Software } \\
\text { development, } \\
\begin{array}{l}\text { IT-consulting } \\
\text { and other } \\
\text { related services }\end{array}\end{array}$ & 0.09 & 0.22 & 0.25 & 0.16 \\
\hline $\begin{array}{l}\text { Production of } \\
\text { computers, and } \\
\text { electronic and } \\
\text { optical devices }\end{array}$ & 0.09 & 0.109 & 0.25 & 0.14 \\
\hline $\begin{array}{l}\text { Wholesale and } \\
\text { retail trade }\end{array}$ & 0.146 & 0.236 & -0.014 & 0.04 \\
\hline $\begin{array}{l}\text { Manufacturing } \\
\text { of electrical } \\
\text { equipment }\end{array}$ & 0.05 & 0.25 & 0.08 & 0.1 \\
\hline
\end{tabular}

In order to highlight the sectors and dominant production factors, it is necessary to look at the maximum values. For example, in almost all studied sectors of activity the key factor is labor. The labor factor is presented in the process of production by labor of the highest qualification employees. The labor and other factors of production initiates the production process as such. It is also important to know and understand that the labor factor of production activity is manifested not only in the number of employees and labor costs, but equally in the quality and efficiency of the labor, in the labor output [7]. Actual calculations take into account not only the labor expended, but also its productivity.

A significant role of innovations in the efficient use of production factors in the sectors related to information and communication technologies should also be noted. A small portion of expenditures on innovations in the medium and low technology sectors, operating in the region, should be mentioned.

It should be noted that in the sectors with a sufficiently high level of one of the dominant factors, the calculation of the production function has shown an effective use of a production factors combination, see Fig. 1.

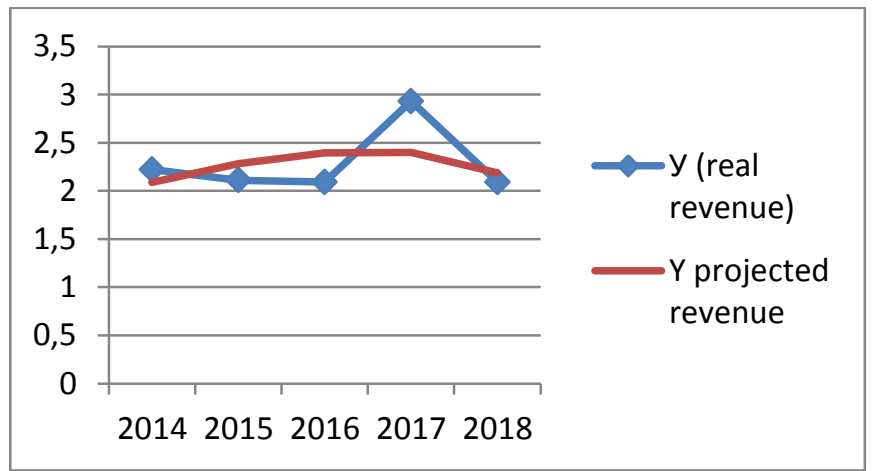

Fig. 1. Comparative analysis of estimated $\mathrm{Y}$ and real $\mathrm{Y}$ profit in the sector of "Software development, IT-consulting and other related services" 
Basing on the calculations, we can conclude that the availability of highly qualified personnel is the key production factor for the Southern Federal District now. In this connection it is rational to find such forms of interaction between employers and universities that will result in forming the competences demanded by the new labor market.

The competence model of education, that is a compilation of university, employer and personal qualities of the graduate himself, aims at providing the effectiveness of modern graduates and the guarantees of high level of education. As noted by T.A. Razuvaeva, the structure of competence consists of the following:

1. activity component, that is a set of skills and modes of action;

2. cognitive component, a body of knowledge on the implementation of certain actions;

3. motivational component, since the implementation of competencies takes place in a variety of activities to solve the theoretical and practical problems;

4. experience, an integration of the learned by students individual actions, ways and methods of solving problems into a single unit [8].

In essence, the competence approach presupposes the formation and development of core competencies providing the university graduate with a successful social adaptation and functional tasks performance [9]. Mastering the educational programs, the graduate acquires basic knowledge and skills that should be developed further and supplemented with professional competences, which are then transformed into intellectual capital of the enterprise $[2,5]$. Therefore, in order to form the demanded competencies, the scientific and educational processes must be adapted to the changing needs of employers. This corresponds to a form of partnership implemented by means of the employer's participation in the formation of the educational program. The employer shares his opinion on demanded competencies, which should be formed in the student. All the above data together with the basic disciplines, as well as the personal qualities of the graduate, the so-called soft-skills, are taken into account when preparing the university curriculum. The changes in the labor market lead to the fact that experts need knowledge in not only their professional field, but also the related fields. This determines the need to develop a system of additional vocational education and training for both university staff and employers [4]. The formation of project teams for working on projects in subject areas proposed by employers should be effective. For example, the formation of project teams consisted of trainees studying different subject areas provides an interdisciplinary interaction and formation of competences in different areas.

\section{SUGGESTIONS AND RECOMMENDATIONS ON THE RESEARCH RESULTS}

The knowledge, as the primary productive force and the main productive resource, serves as the fundamental basis of the new economy, thus, the human potential becomes a key factor in production processes. The necessity to find effective forms of interaction between employers and universities is caused by the fact that the training of the specialists demanded in the labor market is impossible without the participation of potential employers. The priority form of cooperation between employers and universities is the cooperation in forms and methods of highly qualified specialists training on the basis of competencies required by employers. We propose to develop the following forms of cooperation between employers and universities: involvement of employers in the development of educational programs; joint implementation of research projects; involvement of students in solving specific scientific and engineering issues in practical training and preparing graduation qualification works on demand of enterprises; targeted training in popular areas; implementation of training programs for employees; organization of training for researchers and lecturers at enterprises.

The interaction between enterprises and universities on a regular basis will enable universities to constantly monitor emerging technological and market trends, determine the list of competencies demanded in future. This will lead to the development of university competences and make it more competitive.

\section{CONCLUSIONS}

Development of forms of interaction between universities and employers in the process of preparing graduates with the competencies needed at the present stage of the digital economy development will provide enterprises with highly qualified staff, and, in their turn, enterprises will use the scientific potential of universities.

An active involvement of employers in the scientific and educational process will ensure the implementation of the educational model which allows creating individual trajectories in students training through the introduction of various forms of project and research work in cooperation with enterprises. This will ensure the formation and development of professionals through their integration in the modern business environment by means of the unique teaching methods that are adapted to current market conditions. The development of forms of cooperation between universities and employers will allow bridging the gap between the needs of the industrial sector for highly qualified personnel and capabilities of universities to prepare such personnel.

\section{REFERENCES}

[1] Babikova A.V., Kaplyuk E.V. Prospects of technological development of industry on the basis of interaction between universities and industrial enterprises. Proceeding of 2017 IEEE 6th Forum Strategic Partnership of Universities and Enterprises of Hi-Tesh Branches (Science. Education. Innovation), SPUE 2017-2018-January. C.84-87.

[2] Asaliev A.M. Formation of professional competencies of workers for the needs of the digital economy. Vestnik REA im. G.V. Plekhanova [Bulletin of REA named after G.V. Plekhanov]. 2018. No. 6 (102). Pp. 67-76. (In Russian)

[3] Gaynanov D.A., Klimentyev A.Yu. Priorities of staffing for the digital economy. Kreativnaya ekonomika [Creative Economy]. 2018. Volume 12. No. 12. Pp. 1963-1976. doi: 10.18334 / ce.12.12.39679 (In Russian)

[4] Coomaraswamy A. (ed.). Essays in Post-Industrialism: A Symposium of Prophecy Concerning the Future of Society. London. 1914. 283 p.

[5] Danilchenko M.V., Kudryavtsev S.V., Teselkin S.F. Strategic partnership with universities as the most important factor in ensuring the competitiveness of high technology industrial enterprises. Vestnik NPO 
im. S.A. Lavochkina [Bulletin of the NGO named after S.A. Lavochkina]. 2017. No. 1 (35). Pp. 93-99. (In Russian)

[6] Kondrasheva N.N., Alexandrova A.V., Eremskaya L.I. Formation of digital competencies of specialists of aviation industry enterprises. Nauka i biznes: puti razvitiya [Science and Business: Development Paths]. 2017. No. 11. P. 50-53. (In Russian)

[7] Marshall A. Principy ekonomicheskoj nauki: $v 3$ t.; per. $s$ angl [Principles of economic science: in 3 volumes; per. from English] M.: Progress Publ., 1993. V. III. (In Russian)

[8] Razvadovskaya Yu.V., Hanina A.V. Assessment of the production potential of industries in the industrial sector of the economy: determinants, indicators, trends. Ekonomicheskij analiz: teoriya $i$ praktika [Economic analysis: theory and practice]. 2017. Volume 16. No. 1 (460). P. 69-81. (In Russian)
[9] Razuvaeva T.A. A competency-based education model: a brief analysis of key concepts and implementation problems Izvestiya PGPU im. V.G. Belinskogo [Proceedings of the PSPU named after V.G. Belinsky] 2012. No. 28. S. 986-989. (In Russian)

[10] Solonitsyn V. A. The competency-based approach and the quality of the educational process at the university. Obrazovatel'nye resursy $i$ tekhnologii [Educational resources and technologies]. 2013. No. 1 (2). P. 12-18. (In Russian)

[11] Federal State Statistics Service. [Electronic resource] URL: https://www.gks.ru (accessed: 05.10.2019). (In Russian)

[12] Shabaeva S.V., Kekkonen A.L. A practical study of cooperation between universities and business in Russia and EMCOSU countries. Universitetskoe upravlenie: praktika i analiz [University Management: Practice and Analysis]. 2017. Volume 21. No. 6. P. 93-100. (In Russian) 